\title{
Teacher's Perspectives on Development of Oral Health Education Intervention (OHEI) for 6 - 12 Year Children in Thiruvananthapuram District, Kerala - A Qualitative Study
}

\section{Neethu Suresh ${ }^{1 *}$, V Raman Kutty², KR Thankappan ${ }^{3}$, K Nanda Kumar ${ }^{4}$, P Sankara Sarma ${ }^{5}$ and Aravind A Vijayan ${ }^{6}$}

${ }^{1}$ Reader, PMS College of Dental Science and Research, Vattapara,

Thirivananthapuram, Kerala and PhD Scholar Sree Chitra Tirunal Institute for

Medical Sciences and Technology (SCTIMST), Trivandrum, India

${ }^{2}$ Research Director, Amala Cancer Research Centre, Thrissur, Kerala, India

${ }^{3}$ Professor, Department of Public Health and Community Medicine, Central University

Kasargod, Kerala, India

${ }^{4}$ Dean, Azeezia Dental College, Kollam, India

${ }^{5}$ Professor and Head, Achutha Menon Centre for Health Science Studies (AMCHSS),

Thiruvananthapuran, Kerala

${ }^{6}$ Assistant Professor, Department of Dentistry, Mount Zion Medical College,

Pathanamthitta, Kerala, India

*Corresponding Author: Neethu Suresh, Reader, PMS College of Dental Science and Research, Vattapara, Thirivananthapuram, Kerala and PhD Scholar Sree Chitra Tirunal Institute for Medical Sciences and Technology (SCTIMST), Trivandrum, India.
Received: March 26, 2021

Published: April 23, 2021

(C) All rights are reserved by Neethu Suresh., et al.

\footnotetext{
Abstract

Background: For the successful planning, development and implementation of any oral health education (OHE) intervention for children we need inputs from parents, teachers, basic ideas regarding oral health related knowledge, attitude and practices of the children. The most appropriate time to provide OHE to children is 6 - 12 years, because it is the time of mixed dentition; first permanent tooth erupt by the age of six years. Children with poorer oral health status are more likely to experience dental pain and miss many hours of school due to oral pain and related problems. Our study aimed to find out teachers' perspectives on development of Oral Health Education Intervention (OHEI) for 6 - 12-year old children.

Methods: It was a qualitative study. Six focus group discussions (FGDs) were conducted among 42 teachers to find out their perspectives on OHEI classes for 6 - 12-year old children.

Results: We found that children need awareness regarding good oral hygiene practices, good dietary habits, and harmful effects of tobacco. Parents need awareness regarding importance of regular dental check-ups. Tooth decay and gum diseases are the most common oral health problems seen among children. Oral health needs to be given adequate importance in schools. Oral health problems were one of the main reasons for absenteeism in schools. OHEI programs can be implemented in schools, teachers' participation should be ensured for OHEI classes, smart class rooms could be effectively utilized to conduct OHEI classes and short span classes in the morning with videos would be suitable for conducting OHEI classes.

Conclusion: We believe that our findings would help to plan successful Oral Health Education Intervention (OHEI) programs for 6 12-year-old children in future.
}

Key words: Oral; Health; Education; Teacher; Intervention; Program 
Teacher's Perspectives on Development of Oral Health Education Intervention (OHEI) for 6 - 12 Year Children in Thiruvananthapuram District, Kerala - A Qualitative Study

\section{Abbreviations}

OHEI: Oral Health Education Intervention; FGDs: Focus group discussions; OHE: Oral Health Education; UP: Upper Primary; HS: High Schools; HSS: Higher Secondary Schools; EVS: Environmental studies

\section{Introduction}

Oral Health Education (OHE) is an important method of public health intervention that aims to improve knowledge, which may lead to the adoption of favourable oral health behaviours that contribute to better oral hygiene status and in turn better oral health [1]. The most appropriate time to provide OHE to children is 6 12 years, because it is the time of mixed dentition; first permanent tooth erupts by the age of 6 years. According to Erikson's 8 Stages of Psychosocial Development children in 6 - 12 years of age group are productive and they learn the pleasure of applying themselves to the task and feel pride in their accomplishments [2]. According to Piaget's theory this age group acquire and use cognitive operations such as mental activities that are components of logical thought [3]. Schools provide the most favourable environment to impart oral health education to children because they provide an efficient and effective way to reach out to children. Children with poorer oral health status are more likely to experience dental pain and miss many hours of school due to oral pain and related problems.

For the successful planning, development and implementation of any oral health education intervention for children we need inputs from parents, teachers, basic ideas regarding oral health related knowledge, attitude and practices of the children. In the systematic review of school based oral health education programs in India we found that none of the studies had focused on getting teachers' perspectives while developing the intervention program [4].

\section{Aim of the Study}

Our study aims to find out teacher's perspectives on development of Oral Health Education Intervention (OHEI) for 6 - 12 year children. We believe that our findings would help to plan successful Oral Health Education Intervention (OHEI) for children in future.

\section{Materials and Methods}

Study setting

The study was conducted in Thiruvananthapuram educational district.
The focus group discussions (FGDs) were conducted by the first author a female dentist with a Master of Dental Science MDS., She is a Ph.D scholar and had undergone training to conduct qualitative research. The interviewer had visited the participants prior to the interview to give them information regarding the study and to build a rapport with the participants. The information participants had regarding the interviewer was that she is a dentist doing research to find out the opinions of school teachers of young children in developing oral health education classes for 6 - 12-year-old children.

In this study we followed the Grounded Theory Approach. The sampling method was purposive. The participants were approached in the schools and the interviews were conducted in a face-to-face manner. Total of 42 participants were there. Six participants dropped out of the study. Two of them had to drop out because they had to attend an emergency meeting with the Headmaster of the school. Two of them had to drop out because they were given class duty by the Headmaster of the school. The rest two of them had to drop out because they were on leave on the day of interview due to personal reasons.

Total of six FGDs were conducted in six separate schools. All the six schools were Government schools. Two of the schools were Higher Secondary Schools and four of them were Upper Primary Schools. None of them had hostel facilities. All the children were day scholars.

Four FGDs were conducted in Staff rooms and two FGDs were conducted in vacant class rooms in the corresponding schools. Among the 42 participants 36 participants were females and six participants were males. The mean age of the female participants was 36 years and that of the male participant was 27 years.

We used a pilot tested interview guide for the FGDs. The interview guide mainly focused on two aspects. First one was "what comes to a teachers' mind when they think of "oral health of children". In this first aspect we probed more regarding Oral hygiene habits of children, dietary habits of children as observed by the teachers, common oral health complaints of children noted by teachers, absenteeism of children from school due to oral health problems, nearby dental care services available to children information, dental visits of children as far as teachers know, and teachers' information on tobacco use among children. 
Teacher's Perspectives on Development of Oral Health Education Intervention (OHEI) for 6 - 12 Year Children in Thiruvananthapuram District, Kerala - A Qualitative Study

In the second aspect of the interview guide we focussed on getting teachers' perspectives on planning oral health education class for 6 - 12-year-old children. In this aspect we probed more regarding - what were teachers' expectations from an oral health education class, whether oral hygiene practices or oral health had been a part of school syllabus, according to teachers which were the suitable time slots and methods to conduct oral health education classes, according to teachers what were the already available facilities in the schools like free periods, class rooms, plug points etc which would help us to conduct oral health education classes, and finally we probed whether the teachers were willing to be part of oral health education programs if such programs were introduced in their schools?

No repeat interviews were carried out. Audio recording of all the six FGDs were done. Field notes were made by the interviewer during all the FGDs. The mean duration of each FGD ranged from 30 to 45 minutes. All the FGDs were continued till data saturation. The transcripts were not returned to the participants for comment or correction, but some inconsistencies were rectified through telephone.

In data analysis, the data were coded by the interviewer (principal investigator) only. Description of coding tree has been provided. The themes were derived from data manually. No software was used. In our study due to time constrains we couldn't ask for participant feedback on the findings.

Participant reports were presented to illustrate themes. There was consistency between data presented and the findings. Major themes and minor themes are clearly discussed in the results.

\section{Results}

Oral hygiene habits of children

According to the teachers the most common materials used by the children to clean their teeth were tooth brush and tooth paste. Children also used charcoal either occasionally or regularly. Some teachers even advised children to use charcoal to get rid of the yellow stains on the teeth. Children used tongue cleaners or midrib of coconut leaf to clean their tongue. Most of the children did not wash their mouth after eating snacks.

"It is believed that if we clean teeth with charcoal applying pressure, we can recline forwardly placed teeth....but we have also heard that if you apply pressure and brush, teeth can wear off ....now there are tooth paste containing charcoal...so we are confused..."
Coding tree for oral hygiene habits of children

\begin{tabular}{|l|ll|}
\hline \multicolumn{2}{|c|}{ Coding Tree for oral hygiene habits of children } \\
\hline Initial coding & $\bullet$ & Children used charcoal to clean teeth \\
& $\bullet$ & $\begin{array}{l}\text { Even some teachers advised the use of } \\
\text { charcoal }\end{array}$ \\
& $\bullet \begin{array}{l}\text { Children used tongue cleaners and mid- } \\
\text { rib of coconut leaf to clean tongue } \\
\text { Children did not wash their mouth after } \\
\text { eating snacks }\end{array}$ \\
\hline $\begin{array}{l}\text { Intermediate } \\
\text { coding }\end{array}$ & $\bullet \begin{array}{l}\text { Children had incomplete awareness re- } \\
\text { garding good oral hygiene practices }\end{array}$ \\
\hline Advanced coding & $\bullet \begin{array}{l}\text { Children needed awareness regarding } \\
\text { good oral hygiene practices }\end{array}$ \\
\hline
\end{tabular}

\section{Dietary habits of children}

The schools didn't have any school dental program, nor dental records maintained, but the teachers' assessment on the common dietary habits of the children were based on their daily observation of the children and their years of experience with the children.

Teachers reported that most children ate the breakfast and lunch given to them from the school. Children like sweets and bakery foods. Children are also fond of packet food items like 'ok biriyani', Kurkure, lays, pickle packets, packet juices like 'zíp up' and various types of sweets like 'sweete', 'pulimuttayi' and 'kattamuttayi'. In schools with scarcity of water, many children drank pipe water when their bottle water was over.

"The children....they like packet foods also....packet food like 'ok biriyani' cost only rupees 5...children buy it with their pocket money...sometimes many children share one packet".

Coding tree for dietary habits of children

\begin{tabular}{|l|ll|}
\hline \multicolumn{2}{|c|}{ Coding tree for dietary habits of children } \\
\hline Initial coding & $\bullet$ & $\begin{array}{l}\text { Children are fond of bakery foods } \\
\text { During water scarcity children drank pipe } \\
\text { water }\end{array}$ \\
\hline $\begin{array}{l}\text { Intermediate } \\
\text { coding }\end{array}$ & $\bullet \begin{array}{l}\text { Children had incomplete awareness regard- } \\
\text { ing good dietary practices }\end{array}$ \\
\hline $\begin{array}{l}\text { Advanced } \\
\text { coding }\end{array}$ & $\bullet \begin{array}{l}\text { Children needed awareness regarding good } \\
\text { dietary practices }\end{array}$ \\
\hline
\end{tabular}

\section{Common oral health complaints of children}

The schools didn't have any school dental program, nor dental records maintained, but the teachers assessment on the common 
Teacher's Perspectives on Development of Oral Health Education Intervention (OHEI) for 6 - 12 Year Children in Thiruvananthapuram District, Kerala - A Qualitative Study

dental problems seen in children were based on their daily observation of the children and their years of experience with the children. In schools young children always report their health related problems including oral health related problems to their teachers.

Tooth decay, swelling in gums, retained milk teeth, irregularly placed teeth were the common oral health complaints of children reported by the teachers. Tooth decay and gum problems were the most common oral health complaints reported by the teachers.

"Nowadays milk teeth have to be extracted...they don't shed in time.....new teeth come irregularly".

Coding tree for common oral health complaints of children

\begin{tabular}{|l|l|}
\hline \multicolumn{2}{|c|}{ Coding tree for common oral health complaints of children } \\
\hline Initial coding & $\begin{array}{l}\text { Tooth decay, swelling in gums, retained } \\
\text { milk teeth, irregularly placed were the oral } \\
\text { health common problems seen in children }\end{array}$ \\
\hline $\begin{array}{l}\text { Intermediate } \\
\text { coding }\end{array}$ & $\begin{array}{l}\text { Tooth decay and gum problems were the } \\
\text { most common oral health problems seen in } \\
\text { children }\end{array}$ \\
\hline $\begin{array}{l}\text { Advanced } \\
\text { coding }\end{array}$ & $\begin{array}{l}\text { Tooth decay and gum problems were the } \\
\text { most common oral health problems seen in } \\
\text { children }\end{array}$ \\
\hline
\end{tabular}

Absenteeism of children from school due to oral health problems

Teachers reported that in last six months most children had taken one to two days of leave due to oral health problems. In the last six months some children even had taken up to five days of leave from school.

"One of my students took five days leave, "he had tooth pain and swelling.....and after tooth extraction...it took some time for the swelling to go.. so he missed the school".

Coding tree for absenteeism of children from school due to oral health problems

\begin{tabular}{|c|c|}
\hline \multicolumn{2}{|c|}{$\begin{array}{c}\text { Coding tree for absenteeism of children from school due to } \\
\text { oral health problems }\end{array}$} \\
\hline $\begin{array}{l}\text { Initial co- } \\
\text { ding }\end{array}$ & $\begin{array}{l}\text { - In the last six months most of the children } \\
\text { had taken one or two days of leave from } \\
\text { school due to oral health problems }\end{array}$ \\
\hline $\begin{array}{l}\text { Intermediate } \\
\text { coding }\end{array}$ & $\begin{array}{l}\text { - Oral health problems were affecting the } \\
\text { school attendance of most of the children }\end{array}$ \\
\hline $\begin{array}{l}\text { Advanced } \\
\text { coding }\end{array}$ & $\begin{array}{l}\text { - Oral health problems were one of the main } \\
\text { reasons for absenteeism in schools }\end{array}$ \\
\hline
\end{tabular}

Nearby available dental care services and dental visits of children

The study we did not directly assess the utilization of dental services of the students. It was done from the teacher's perspective. In schools young children always report their health related problems including oral health related problems to their teachers. Teachers are aware of the nearby dental care facilities. They report the health issue of the children to the parent and keep a track on the how the health issue was resolved. So, teachers were able to give us good information regarding utilization of dental services by children.

According to the teachers the parents do not take their children for regular dental checkups. But in case of emergencies like trauma and tooth loos, parents immediately take their children to the dentist.

“We don't think they (parents) take the children for regular dental check-up".

Coding tree for nearby available dental care services and dental visits of children

Coding tree for nearby available dental care services and dental visits of children

\begin{tabular}{|l|ll|}
\hline Initial coding & $\bullet$ & $\begin{array}{l}\text { Parents did not take the children for regular } \\
\text { dental check-ups }\end{array}$ \\
\hline $\begin{array}{l}\text { Intermediate } \\
\text { coding }\end{array}$ & $\begin{array}{l}\text { Parents only gave importance to emergency } \\
\text { dental problems like pain and trauma }\end{array}$ \\
\hline $\begin{array}{l}\text { Advanced } \\
\text { coding }\end{array}$ & $\begin{array}{l}\text { Parents had incomplete awareness regard- } \\
\text { ing the importance of regular dental check- } \\
\text { ups }\end{array}$ \\
\hline
\end{tabular}

Tobacco use among children

Teachers reported that in upper primary (UP) schools they had not noticed any tobacco use among the children. In high schools (HS) and higher secondary schools (HSS) the UP-class children sometimes pick up and use the discarded cigarette pieces left by the elder children in the common toilet area.

"In our school we have high school children also.... young children get influenced by them... all of them share common toilet...sometimes young children pick up the cigarette pieces left there by elder students and try to use them". 
Teacher's Perspectives on Development of Oral Health Education Intervention (OHEI) for 6 - 12 Year Children in Thiruvananthapuram District, Kerala - A Qualitative Study

Coding tree for tobacco use among children

\begin{tabular}{|l|ll|}
\hline \multicolumn{2}{|c|}{ Coding Tree for tobacco use among children } \\
\hline Initial coding & $\bullet \begin{array}{l}\text { Young children had a tendency to imitate } \\
\text { older children }\end{array}$ \\
\hline $\begin{array}{l}\text { Intermediate } \\
\text { coding }\end{array}$ & $\bullet \begin{array}{l}\text { Children had incomplete awareness regard- } \\
\text { ing the harmful effects of tobacco }\end{array}$ \\
\hline $\begin{array}{l}\text { Advanced } \\
\text { coding }\end{array}$ & $\bullet \begin{array}{l}\text { Children needed awareness regarding the } \\
\text { harmful effects of tobacco }\end{array}$ \\
\hline
\end{tabular}

Whether oral hygiene practices or oral health had been a part of school syllabus

Teachers reported that in Environmental studies (EVS) children had to learn about daily hygiene practices which included morning tooth brushing. During physical education classes of younger children they asked the children whether they had brushed their teeth and cut their nails, but physical education teachers were not posted in many schools.

"During physical education classes teachers usually ask children regarding tooth brushing and nail cutting...but now we don't have a specific teacher ...other subject teachers take physical education so it does not get much importance".

Coding tree for whether oral hygiene practices or oral health had been a part of school syllabus

\section{Coding tree for whether oral hygiene practices or oral health had beena part of school syllabus}

\begin{tabular}{|l|ll|}
\hline Initial coding & $\bullet$ & $\begin{array}{l}\text { There is no special class, teachers or pro- } \\
\text { grams to address oral health in schools. }\end{array}$ \\
\hline $\begin{array}{l}\text { Intermediate } \\
\text { coding }\end{array}$ & $\bullet \begin{array}{l}\text { Oral health is getting side-lined in schools } \\
\text { due other issues. }\end{array}$ \\
\hline $\begin{array}{l}\text { Advanced } \\
\text { coding }\end{array}$ & $\bullet \begin{array}{l}\text { Oral health needs to be given adequate im- } \\
\text { portance in schools }\end{array}$ \\
\hline
\end{tabular}

\section{Suitable time and methods to conduct OHEI classes}

According to teachers' use of visual media like videos were the best ways to convey information to children. Teachers reported that children are more attentive during the morning class hours especially during $10 \mathrm{am}$ to 11:30 am. According to the teachers the children had an attention span of 20 to 30 minutes. Teachers also reported that illustrating the main points in posters or charts and pasting them in the class rooms would help the children to remind the main points.
"Children like to watch videos...best time to teach is morning 10 to 11:30...after that they start feeling hungry...after lunch some of them feel sleepy...attention span is about 20 to 30 minutes ...some children have more attention span".

Coding tree for suitable time and methods to conduct OHEI classes

\begin{tabular}{|c|c|}
\hline \multicolumn{2}{|c|}{$\begin{array}{l}\text { Coding Tree for suitable time and methods to conduct OHEI } \\
\text { classes }\end{array}$} \\
\hline Initial coding & $\begin{array}{l}\text { - Attention span of children is about } 20 \text { to } 30 \\
\text { minutes } \\
\text { - } \quad \text { Best time to take classes would be morning } \\
\text { hours } \\
\text { - Videos are the best way to convey informa- } \\
\text { tion to children }\end{array}$ \\
\hline $\begin{array}{l}\text { Intermediate } \\
\text { coding }\end{array}$ & $\begin{array}{l}\text { - Suitable time would be morning hours, span } \\
\text { not exceeding } 30 \text { minutes and using videos }\end{array}$ \\
\hline $\begin{array}{l}\text { Advanced } \\
\text { coding }\end{array}$ & $\begin{array}{l}\text { - Short span classes in the morning with vid- } \\
\text { eos would be suitable for conducting OHEI } \\
\text { classes }\end{array}$ \\
\hline
\end{tabular}

Available facilities in the schools for conducting OHEI classes

Teachers reported that all schools have smart class rooms with laptops and projectors.

"All schools have smart classrooms...we have laptops and projectors children are familiar to those classrooms".

Coding Tree for available facilities in the schools for conducting OHEI classes

\begin{tabular}{|c|c|}
\hline \multicolumn{2}{|c|}{$\begin{array}{l}\text { Coding tree for available facilities in the schools for con- } \\
\text { ducting OHEI classes }\end{array}$} \\
\hline Initial coding & $\begin{array}{l}\text { - Smart class rooms with laptops and projec- } \\
\text { tors were available in all schools } \\
\text { - Children were familiar with these class } \\
\text { rooms }\end{array}$ \\
\hline $\begin{array}{l}\text { Intermediate } \\
\text { coding }\end{array}$ & $\begin{array}{l}\text { - Smart class rooms are available to conduct } \\
\text { OHEI classes }\end{array}$ \\
\hline $\begin{array}{l}\text { Advanced } \\
\text { coding }\end{array}$ & $\begin{array}{l}\text { - Smart class rooms could be effectively uti- } \\
\text { lized to conduct OHEI classes }\end{array}$ \\
\hline
\end{tabular}

Expectations of the teachers regarding the OHEI class

Teachers expected the OHE classes to cover topics like tooth brushing technique, how much tooth paste must be taken, importance of twice daily brushing, whether use of charcoal or not etc. 
Teacher's Perspectives on Development of Oral Health Education Intervention (OHEI) for 6 - 12 Year Children in Thiruvananthapuram District, Kerala - A Qualitative Study

“Children don't know the correct method of brushing.... how much paste to take....even we are confused whether charcoal is good for teeth or not".

Coding tree for expectations of the teachers regarding the OHEI class

\begin{tabular}{|l|l|}
\hline \multicolumn{2}{|c|}{ Coding tree for expectations of the teachers regarding the } \\
OHEI class
\end{tabular}

\section{Willingness of teachers to be part of future OHEI programs}

Teachers reported that they are willing to be part of any upcoming OHE program and remind the children regarding twice daily brushing.

"We are happy to remind them(children) regarding brushing two times...our work schedule is very tight...so. we won't get time to attend OHE classes".

Coding tree for willingness of teachers to be part of future OHEI programs

\begin{tabular}{|c|c|}
\hline \multicolumn{2}{|c|}{$\begin{array}{l}\text { Coding tree for willingness of teachers to be part of future } \\
\text { OHEI programs }\end{array}$} \\
\hline Initial coding & $\begin{array}{l}\text { - Teachers were willing to be part of OEHI } \\
\text { classes and remind children regarding twice } \\
\text { daily tooth brushing }\end{array}$ \\
\hline $\begin{array}{l}\text { Intermediate } \\
\text { coding }\end{array}$ & $\begin{array}{l}\text { - Teachers are willing to be part of OHEI } \\
\text { classes }\end{array}$ \\
\hline $\begin{array}{l}\text { Advanced } \\
\text { coding }\end{array}$ & $\begin{array}{l}\text { - Teachers participation should be ensured } \\
\text { for OHEI classes }\end{array}$ \\
\hline
\end{tabular}

The main points from the FGDs with teachers are summarized in table 1.

\begin{tabular}{|c|c|}
\hline Sl No & Findings \\
\hline 1 & $\begin{array}{l}\text { Children need awareness regarding } \\
\text { - } \quad \text { Good oral hygiene practices } \\
\text { - } \quad \text { Good dietary habits } \\
\text { - } \quad \text { Harmful effects of tobacco }\end{array}$ \\
\hline 2 & $\begin{array}{l}\text { Tooth decay and gum diseases were the most common } \\
\text { oral health problems seen among children }\end{array}$ \\
\hline 3 & $\begin{array}{l}\text { Parents need awareness regarding importance of regu- } \\
\text { lar dental check ups }\end{array}$ \\
\hline 4 & $\begin{array}{l}\text { Oral health needs to be given adequate importance in } \\
\text { schools }\end{array}$ \\
\hline 5 & $\begin{array}{l}\text { Oral health problems were one of the main reasons for } \\
\text { absenteeism in schools }\end{array}$ \\
\hline 6 & $\begin{array}{l}\text { OHEI programs can be implemented in schools } \\
\text { - } \quad \begin{array}{l}\text { Teachers participation should be ensured for OHEI } \\
\text { classes }\end{array} \\
\text { - } \quad \text { Smart class rooms could be effectively utilized to } \\
\text { conduct OHEI classes } \\
\text { - Short span classes in the morning with videos } \\
\text { would be suitable for conducting OHEI classes }\end{array}$ \\
\hline
\end{tabular}

Table 1: Summary of findings of FGDs with teachers of 6 - 12 year children.

\section{Discussion}

Our study aimed to find out teacher's perspectives on development of Oral Health Education Intervention (OHEI) for 6 - 12-year children. Our main findings indicated that children need awareness regarding good oral hygiene practices, good dietary habits, and harmful effects of tobacco. Parents need awareness regarding importance of regular dental check-ups. Tooth decay and gum diseases are the most common oral health problems seen among children. Oral health needs to be given adequate importance in schools. Oral health problems were one of the main reasons for absenteeism in schools. OHEI programs can be implemented in schools, teachers' participation should be ensured for OHEI classes, smart classrooms could be effectively utilized to conduct OHEI classes and short span classes in the morning with videos would be suitable for conducting OHEI classes.

Similar findings were reported by Mialhe F in 2015 [6]. According to this study primary school teachers from Brazil had reported 
Teacher's Perspectives on Development of Oral Health Education Intervention (OHEI) for 6 - 12 Year Children in Thiruvananthapuram District, Kerala - A Qualitative Study

that in schools oral health was not given due importance, parents were not aware regarding the importance of oral health, children needed awareness regarding oral hygiene practices and schools lacked services of specialists like dentists [6].

In the study from 2019, the teachers for 7 - 11 years from England reported that children needed awareness regarding good dietary habits and they are willing to be part of OHE classes [7]. The head teachers from Tamil Nadu also reported that in schools oral health was not given adequate importance and schools need OHEI programs [8].

We believe that our findings would help to plan successful Oral Health Education Intervention (OHEI) programs for 6 - 12 year children in future classes.

\section{Strengths of the Study}

1) The study had been conducted completely based on the Consolidated criteria for Reporting Qualitative research.

2) Our findings gives a comprehensive view on teachers' perspectives on development of Oral Health Education Intervention (OHEI) for 6 - 12-year old children.

3) We believe that our findings would help to plan successful Oral Health Education Intervention (OHEI) programs for 6 12-year-old children in future.

\section{Limitations of the Study}

1) No repeat interviews were carried out.

2) In data analysis, the data were coded by the interviewer (First author) only.

3) In our study due to time constrains we couldn't ask for participant feedback on the findings.

\section{Conclusion}

Children need awareness regarding good oral hygiene practices, good dietary habits, and harmful effects of tobacco. Parents need awareness regarding importance of regular dental check-ups. Tooth decay and gum diseases are the most common oral health problems seen among children. Oral health needs to be given adequate importance in schools. Oral health problems were one of the main reasons for absenteeism in schools. OHEI programs can be implemented in schools, teachers' participation should be ensured for OHEI classes, smart class rooms could be effectively utilized to conduct OHEI classes and short span classes in the morning with videos would be suitable for conducting OHEI classes.

\section{Patents}

Nil.

\section{Author Contribution Details}

The manuscript has been read and approved by all the authors. All authors had contributed in concept, design, data analysis, statistical analysis, manuscript preparation, manuscript editing and manuscript review. Each author believes that the manuscript represents honest work and authors alone are responsible for the content and writing of the paper.

\section{Funding}

Nil.

\section{Institutional Review Board Statement}

The study got approval and clearance from the Institutional Ethics Committee (IEC) of Sree Chitra Tirunal Institute for Medical Sciences and Technology (SCTIMST) (IEC Regn No. ECR/189/ Inst/KL/2013). Written permission from the Additional Director of Public Instruction, Kerala and the Deputy Director of Education Thiruvananthapuram had been obtained.

\section{Informed Consent Statement}

Participant information sheets were given to participants, informed consent were obtained from the teachers.

\section{Data Availability Statement}

Hard and soft copies of data are available with Principal investigator.

\section{Conflict of Interest}

Nil.

\section{Sample Availability}

Not applicable.

\section{Bibliography}

1. Glanz K., et al. "Health behavior and health education: Theory, research, and practice ( $4^{\text {th }}$ edition)". Jossey-Bass (2008).

2. Erikson's 8 Stages of Psychosocial Development | Education, Society, and the K-12 Learner (2021). 
3. Piaget's Theory of Cognitive Development: behaviorism, cognitive, development, en, jean, piaget, psychology, social, studies, theory | Glogster EDU - Interactive multimedia posters (2021).

4. Gambhir RS., et al. "Impact of School Based Oral Health Education Programmes in India: A Systematic Review". Journal of Clinical and Diagnostic Research 7 (2013): 3107-3110.

5. Griffiths W. "The Principle of Participation: Some Points to Consider". Health Education Journal: SAGE Journals 17 (1959): 222-229.

6. Mialhe F. "Teachers' views about barriers in implement oral health education for school children: a qualitative study". Brazilian Dental Science 17 (2014): 65-73.

7. Eley C., et al. "Using oral hygiene education in schools to tackle child tooth decay: a mixed methods study with children and teachers in England". Journal of Biological Education 54 (2020): 381-395.

8. Veerasamy A., et al. "Head teachers' views of oral health education in schools in Tamil Nadu, India". Health Education Journal: SAGE Journals 77 (2018): 73-84.

\section{Assets from publication with us}

- Prompt Acknowledgement after receiving the article

- Thorough Double blinded peer review

- Rapid Publication

- Issue of Publication Certificate

- High visibility of your Published work

Website: www.actascientific.com/

Submit Article: www.actascientific.com/submission.php

Email us: editor@actascientific.com

Contact us: +919182824667

Citation: Neethu Suresh., et al. "Teacher's Perspectives on Development of Oral Health Education Intervention (OHEI) for 6 - 12 Year Children in Thiruvananthapuram District, Kerala - A Qualitative Study". Acta Scientific Dental Sciences 5.5 (2021): 115-122. 